\title{
FUNCTIONAL ROLE OF MOSS BIOCRUST IN DISTURBED SEMIARID SHRUBLANDS OF NORTH-EASTERN PATAGONIA, ARGENTINA
}

\author{
KRÖPfl, A. I. ${ }^{1 *}-$ DisTEL, R. A. ${ }^{2}-{ }^{\dagger}$ CECCHI, G. A. ${ }^{3}-$ VILlASUSO, N. M. ${ }^{1}$ \\ ${ }^{1}$ Centro Universitario Regional Zona Atlántica (CURZA), Universidad Nacional del Comahue, \\ 8500 Viedma, Argentina
}

\begin{abstract}
${ }^{2}$ Departamento de Agronomía, Universidad Nacional del Sur, and Centro de Recursos Naturales Renovables de la Zona Semiárida, Consejo Nacional de Investigaciones Científicas y Técnicas de la República Argentina, 8000 Bahía Blanca, Argentina
\end{abstract}

${ }^{3}$ Estación Experimental Agropecuaria Valle Inferior, Convenio Instituto Nacional de Tecnología Agropecuaria (INTA)-Provincia de Río Negro, 8500 Viedma, Argentina

${ }^{*}$ Corresponding author

e-mail:akropfl@yahoo.com.ar; phone: +54-9-2920-60-0921

(Received $16^{\text {th }}$ Oct 2021; accepted $22^{\text {nd }}$ Dec 2021)

\begin{abstract}
Biocrusts are key biotic components of arid and semi-arid ecosystems worldwide. In the semi-arid ecosystems of north-eastern Patagonia, the moss biocrust is present both beneath shrubs and in intershrub spaces. In this study we ran a series of field and greenhouse trials aimed at quantifying the moss biocrust cover at sites that differed in grazing and/or shrub mechanical (chaining) disturbance and evaluating its seed entrapping capacity, and its effect on the superficial water balance and grass seedling growth. Grazing or the combined effect of grazing and chaining impacted negatively on the moss biocrust cover. The presence of moss biocrust facilitated seed entrapment and increased the seed density of perennial grasses in the soil seed bank, improved the superficial water balance, and enhanced grass seedling growth. In conclusion, in the semi-arid shrublands in north-eastern Patagonia, the moss biocrust appeared vulnerable to grazing and shrub mechanical disturbance, and it showed functional roles that may facilitate seedling establishment for perennial grasses.
\end{abstract}

Keywords: grazing disturbance, shrub mechanical disturbance, seed entrapment, water balance, perennial grasses establishment

\section{Introduction}

Biocrusts are key biotic components of arid and semi-arid ecosystems worldwide, due to their important role in primary ecological processes (Maestre et al., 2011; Weber et al., 2016). They are composed of varying proportions of cyanobacteria, algae, microfungi, lichens, and mosses, constituting communities that colonize the soil surface (Belnap and Lange, 2003). Although it was widely accepted that biocrust succession follows a general pattern starting with cyanobacteria and algae and concluding with bryophytes at the later stages, recent studies have proposed that mosses can develop in the early stages of succession under favorable and stable soil conditions (Belnap et al., 2016; Condon and Pike, 2018).

The positive influence of biocrusts on soil surface hydrological processes in semiarid ecosystems has been documented by many authors (e.g., Belnap, 2006; Daryanto et al., 2013; Chamizo et al., 2016; Faist et al., 2017). Soil biocrusts generally increase water infiltration, soil water retention, and decrease evaporative losses, resulting in reduced runoff erosion and an increase in water available for plants. In addition, soil biocrusts 
can increase the superficial soil temperature in the cool season (Xiao et al., 2013). Altogether, the hydric and thermal improvements in the microenvironment determine that biocrusts can represent safe sites for seedling establishment. Moreover, when seeds are secondarily moved by wind, the seed entrapment capacity of biocrusts may contribute to the development of the soil seed bank (Bertiller and Ares, 2011).

On the other hand, soil biocrusts are highly vulnerable to both natural and anthropogenic disturbances (Zaady et al., 2016). Among the latter, domestic livestock grazing is recognized as the most widespread stress factor in grasslands. For instance, in the Monte Desert of Argentina, Gómez et al. (2012) found that grazing negatively impacted on the moss biocrust, which only developed under protection from vascular plants. Similarly, mechanical woody plant control in shrublands can have a negative effect on soil biocrusts, particularly when causing a marked superficial soil disturbance like root ploughing (Daryanto et al., 2013). However, other mechanical treatments for shrub control, such as chaining that produces moderate superficial soil scarification (Stevens and Monsen, 2004), may have less adverse effects on the soil biocrusts. Chaining involves the use of a heavy ship anchor chain towed between two tractors, and represents a common large-scale mechanical disturbance used for shrub control in rangelands (Stephens et al., 2016).

In undisturbed or low-disturbed areas of shrublands in north-eastern Patagonia, Argentina, the moss biocrust is often present both beneath and between shrubs. Contrarily, the moss biocrust proved to be impoverished in areas disturbed by heavy grazing alone or in combination with mechanical shrub control, the latter being a common practice in the region (Kröpfl et al., 2007). However, this observation is just qualitative, since quantitative controlled studies on soil biocrusts are still scarce in Argentina (Navas Romero et al., 2020). In this study we sought to address the extent of the impact of grazing and/or shrub mechanical disturbance by chaining on the moss biocrust cover, and the role of the moss biocrust on seedling recruitment of perennial grasses. Based on the available knowledge we hypothesized (1) that the moss biocrust cover is lowest when chained or unchained conditions are disturbed by heavy grazing, and highest in chained ungrazed conditions, and (2) that the moss biocrust facilitates seedling recruitment of perennial grasses. Therefore, the objectives of our study were (1) to quantify the moss biocrust cover at sites differing in livestock grazing and/or chaining, and (2) to evaluate the moss biocrust seed retention capacity and assess its effect on the superficial water balance and grass seedling growth.

\section{Materials and methods}

\section{Study area}

The study was carried out in 2003, at a site near Viedma, Río Negro province, Argentina. The overall characteristics of the climate, soil and vegetation have been described by Godagnone and Bran (2009). The climate of the area is temperate, semiarid. The long-term average annual precipitation is $395 \mathrm{~mm}$ ( $\mathrm{CV}=35 \%)$. Precipitation peaks in autumn and spring, whereas in winter it rains frequently but in small amounts. The mean annual potential evapotranspiration is $800 \mathrm{~mm}$. Soils are sandy to loamy sands, and taxonomically defined as Typic Torripsaments.

The study area is located in the south-eastern Monte Phytogeographical Province (Cabrera, 1976). The physiognomy of the vegetation is a shrubby steppe, with an overstory dominated by the multi-stemmed evergreen shrub Larrea divaricata Cav. and 
isolated specimens or clumps of Geoffroea decorticans (Gillies ex Hook. and Arn.) Burkart. The understory is a predominantly cool-season grassland dominated by Nassella tenuis (Phil.) Barkworth and Piptochaetium napostaense (Speg.) Hack and accompanied by other perennial grasses, such as Poa ligularis Nees ex Steud. var. ligularis, and Pappostipa speciosa (Trin. and Rupr.) Romaschenko var. speciosa. Perennial grasses start growing at the beginning of autumn and set seed at the end of spring, whereas seeds germinate primarily in the autumn. Annual grasses and forbs are represented mainly by Hordeum murinum L. subsp. leporinum (Link.) Arcang., Bromus hordaceus L., Schismus barbatus (L.) Thell, and Erodium cicutarium (L.) L'Hér. ex Aiton. The soil biocrust is dominated by two moss species, which were identified as Syntrichia princeps (De Not.) Mitt and Ceratodon purpureus (Hedw.) (Prof. Dr. Celina Matteri, Museo Argentino de Ciencias Naturales "Bernardino Rivadavia", Buenos Aires, Argentina, 2000).

\section{Trials}

We ran a series of field and greenhouse trials. The field trials were conducted in a 300 -ha paddock $\left(40^{\circ} 55^{\prime} 04^{\prime \prime} \mathrm{S}\right.$ and $\left.63^{\circ} 07^{\prime} 27^{\prime \prime} \mathrm{W}\right)$ with a long history (over 30 years) of heavy continuous grazing by cattle (stocking rate $\sim 0.1$ cows $\mathrm{ha}^{-1}$ ). The paddock had strips of intact vegetation (Figure 1) alongside strips where the aboveground biomass of shrubs had been mechanically disturbed by chaining 3 years earlier (Figure 2). At the beginning of the study, the shrubs in the chained strips had resprouted from basal buds to a height of less than a meter. In a chained strip there was also a 9-ha grazing exclosure, which was constructed immediately after chaining (Figure 2).

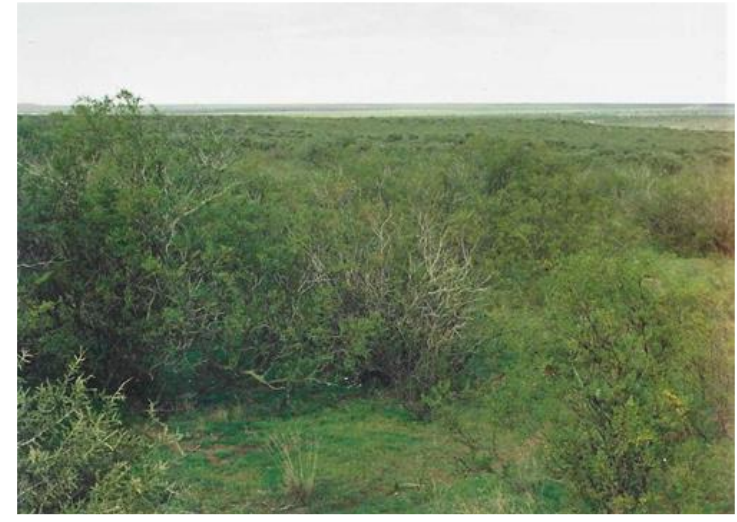

Figure 1. Unchained site

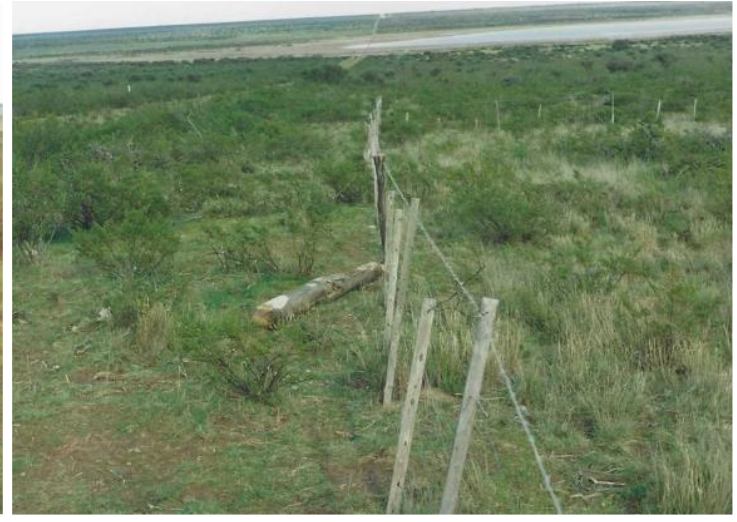

Figure 2. Chained site: at the left side, grazed; at the right side, the ungrazed exclosure

Climatic data of the year are shown in the Appendix Table 1.

\section{Moss biocrust cover}

To evaluate the moss biocrust cover under grazed-chained and grazed-unchained conditions, quadrats $\left(225 \mathrm{~cm}^{2}, \mathrm{n}=26\right)$ were placed at $4 \mathrm{~m}$ intervals along two randomly located line transects $(60 \mathrm{~m}$ each $)$ in both the grazed-chained and grazed-unchained areas. The moss biocrust cover was estimated within the mentioned quadrats in autumn. Immediately before the estimation, the plots were wetted to improve the visibility of the 
moss biocrust (Rosentreter and Eldridge, 2002). A similar procedure was followed to quantify the moss biocrust cover under chained-grazed and chained-ungrazed (exclosure) conditions. In this case, quadrats $\left(225 \mathrm{~cm}^{2}, \mathrm{n}=42\right)$ were placed at $4 \mathrm{~m}$ intervals along two randomly located line transects $(90 \mathrm{~m}$ each) in both the chainedungrazed and adjacent chained-grazed areas. In order to enrich the interpretation of the results, we also placed quadrats $\left(225 \mathrm{~cm}^{2}, \mathrm{n}=42\right)$ inside the exclosure at $4 \mathrm{~m}$ intervals along two randomly located line transects $(90 \mathrm{~m}$ each), to measure both the moss biocrust cover and the grass cover. Each sample was categorized according to whether it was in a mound (beneath shrubs) or flat (intershrub spaces) microsite, and whether it was exposed to the sun or under the shade of grasses.

\section{Moss biocrust seed trap}

To test whether the moss biocrust acts as a seed trap, we buried 30 paired circular plots at random (plastic rings of $23,55 \mathrm{~cm}$ of perimeter) inside the exclosure, in autumn, either with or without moss biocrust, and manually removed all the propagules (seeded fruit with sharp tips and twisted hydro-active awns) of $N$. tenuis in each plot. This task was possible as the awns remain temporarily attached to the propagule and extend above the soil surface. Then we laid down 20 intact propagules of $N$. tenuis on the surface of each plot and recounted them three weeks later. Additionally, we counted the number of seeds of $N$. tenuis in the soil bank in the presence or absence of moss biocrust, before seed germination in the autumn. We randomly extracted 30 paired soil samples $(7.5 \mathrm{~cm}$ diameter, $3.5 \mathrm{~cm}$ deep), either with or without moss biocrust, along a $100 \mathrm{~m}$ transect in the exclosure. From each sample we sorted out moss biocrust, litter and seeds of $N$. tenuis by sieving and manual separation. Then, we determined the dry weight of the moss biocrust and litter and counted the number of seeds collected.

We also tested whether the moss biocrust contributes positively to seed retention under greenhouse conditions. Aluminium trays $(n=20)$ were filled with superficial soil cores $(21 \mathrm{~cm}$ long x $15 \mathrm{~cm}$ wide $\times 4.5 \mathrm{~cm}$ deep) collected from the exclosure in spring, either with or without moss biocrust. Once the trays were on the greenhouse benches all intact seeds of $N$. tenuis were manually removed from each tray. Immediately afterwards, 10 intact seeds of $N$. tenuis were laid down on the surface of each tray, and their permanence was recorded two weeks later. It is worth mentioning that the greenhouse had natural ventilation; therefore, the seeds could be potentially moved by air currents inside it. This test was repeated twice. Greenhouse had no temperature or humidity control, but the trials only lasted some weeks during the spring or the fall.

\section{Moss biocrust and grass seedling growth and survival}

To assess the influence of the moss biocrust on seedling growth of perennial grasses, we randomly selected 30 paired plots $\left(225 \mathrm{~cm}^{2}\right)$ inside the exclosure, either with or without moss biocrust, and marked all the seedlings of the dominant perennial grass $N$. tenuis. Then, we counted the number of tillers and the number of leaves per seedling five times between June and May of the following year. We also recorded the number of new seedlings of $N$. tenuis emerging in the plots during the autumn (March-April-May).

To determine the influence of the moss biocrust on perennial grass seedling survival, in spring we filled pots $(\mathrm{n}=20)$ with soil cores $(7.5 \mathrm{~cm}$ diameter, $14.5 \mathrm{~cm}$ deep) collected from the exclosure, either with or without moss biocrust. Once in the greenhouse, all pots were irrigated to promote germination of the seeds originally present in the soil, and all emerging seedlings were removed. Then, the pots were left untreated until 
autumn when we sowed 10 intact seeds of $N$. tenuis in each one. Afterwards, the pots were watered to maintain field water capacity until germination occurred and then they were thinned to one seedling per pot. The irrigation was discontinued and seedling survival time (days to death) was recorded. We also measured the leaf length, and calculated the leaf relative growth rate of the $N$. tenuis seedlings for three weeks.

\section{Moss biocrust and water balance}

To evaluate the effect of the moss biocrust on the water storage capacity and water evaporation, we extracted undisturbed soil cores from the exclosure in spring, either with or without moss biocrust, and filled pots $(\mathrm{n}=10)$ of $10 \mathrm{~cm}$ in diameter and $5 \mathrm{~cm}$ in depth. Once in the greenhouse, all pots were watered to saturation and weighed prior to allowing them to drain the excess water for 24 hours. Thereafter, irrigation was discontinued, and all pots were weighed daily until reaching a constant weight. The daily loss of water was calculated by difference in weight.

\section{Statistical analyses}

Data were analysed through One-Way ANOVAs and $t$ tests for comparisons between sites or treatments, except for seedling survival that was analysed through the nonparametric Log-Rank test. When necessary, data were transformed to fulfil ANOVA assumptions. We also performed simple linear regression analysis to determine the relationship between the variables of interest. Differences between means were considered significant at $p<0.05$. All analyses were made using the statistical package InfoStat P (Di Rienzo et al., 2017).

\section{Results}

\section{Moss biocrust cover}

Moss biocrust cover was higher $(p=0.0008)$ in the grazed unchained condition $(38.2 \pm 5.4 \%$, mean $\pm 1 \mathrm{SE})$ than in the grazed chained condition $(25.8 \pm 5.4 \%)$ (Appendix Table 2), whereas it was higher $(p<0.0001)$ in the chained ungrazed condition $(46.2 \pm 6.5 \%)$ than in the chained grazed condition (29.5 $44.6 \%)$ (Appendix Table 3).

In flat intershrub microsites of the chained ungrazed condition (exclosure), the moss biocrust cover was higher $(p=0.01)$ in shady $(53.1 \pm 6.2 \%)$ than in sunny conditions $(28.3 \pm 4.1 \%)$, and it did not correlate with grass cover in either sunny $(p=0.13)$ or shady $(p=0.15)$ conditions (Fig. 3a). Similarly, in the mound microsites beneath shrubs, moss biocrusts cover was higher $(p=0.05)$ in shady conditions $(39.2 \pm 5.4 \%)$ than in sunny conditions $(18.1 \pm 9.8 \%)$ and it did not correlate with grass cover in either sunny $(p=0.66)$ or shady $(p=0.97)$ conditions.

In flat intershrub microsites of the chained grazed condition, moss biocrust cover was higher $(p=0.025)$ in shady conditions $(34.6 \pm 6.3 \%)$ than in sunny conditions $(19.4 \pm 3.1 \%)$, and it correlated linearly and positively $(p<0.01)$ with grass cover in sunny conditions only (Fig. 3b). Similarly, in mound microsites beneath shrubs, the moss biocrust cover was higher $(p=0.013)$ in shady conditions $(42.4 \pm 4.7 \%)$ than in sunny conditions $(21.2 \pm 4.0 \%)$, although there was no correlation with grass cover in either sunny or shady conditions. 

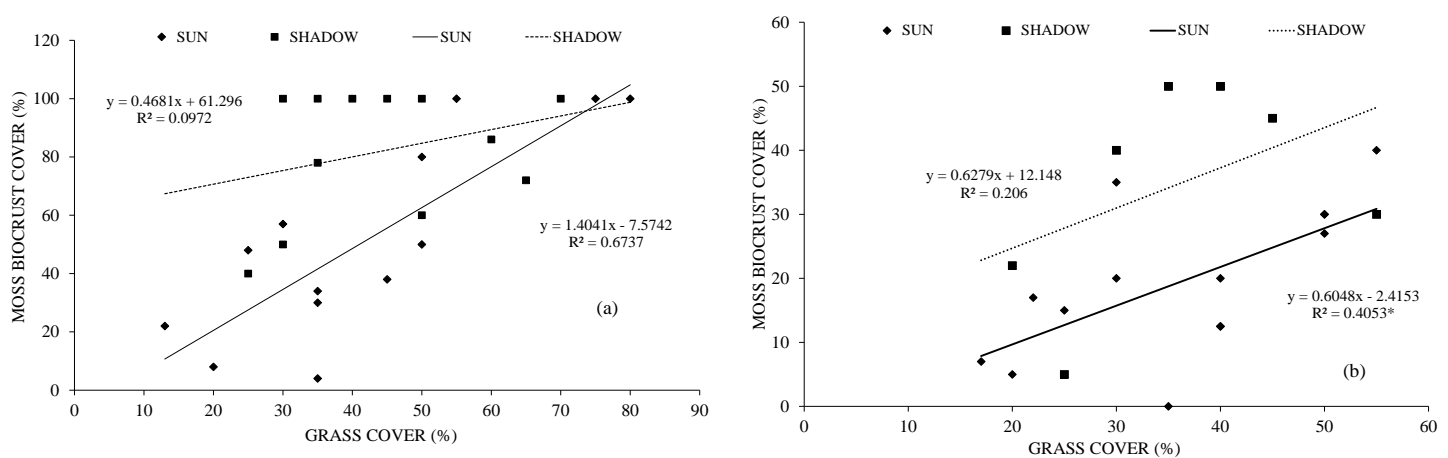

Figure 3. Relationship between moss biocrusts and grass cover in intershrub spaces of either (a) ungrazed $(* * * p<0.001)$ or (b) grazed conditions $(* p<0.05)$, located in either sunny or shady places

\section{Moss biocrust seed retention}

In the experimental plots located in the chained grazing exclosure, the number of seeds of $N$. tenuis retained after three weeks was more than three times higher $(p<0.001)$ with moss biocrust $(13.9 \pm 1.25)$ than without it $(3.7 \pm 0.46)$. Consequently, the number of seeds of $N$. tenuis in the soil seed bank was higher $(p<0.001)$ with moss biocrust $(5.9 \pm 0.68)$ than without it $(1.5 \pm 0.23)$. Similarly, under greenhouse conditions the number of $N$. tenuis seeds retained in the experimental trays was higher $(p<0.001)$ in that presence rather than in the absence of moss biocrust $(6.0 \pm 0.30 \mathrm{vs} .1 .9 \pm 0.29$, and $3.7 \pm 0.37$ vs. $1.9 \pm 0.23$, for the first and the second test, respectively). The seed quantity correlated positively with the biomass of litter in the plots without moss biocrust, and with the biomass of litter plus crust in the plots with moss biocrust (Fig. 4).

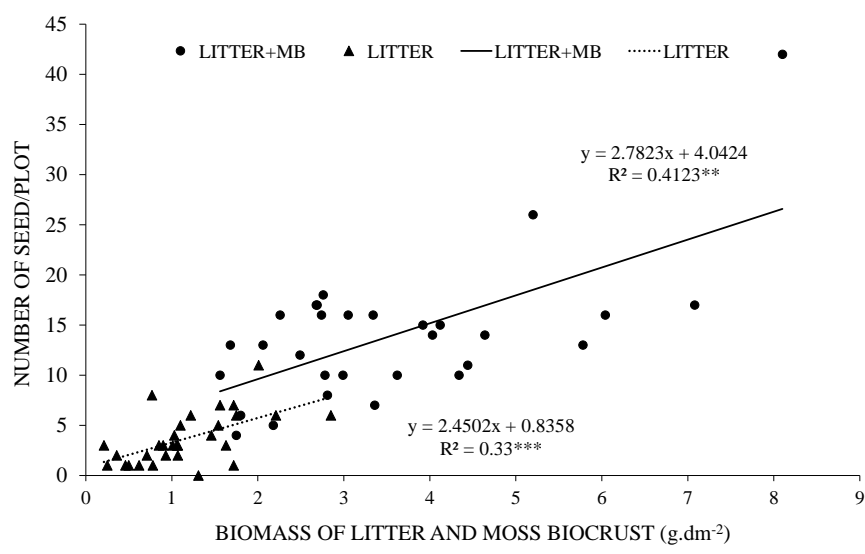

Figure 4. Relationship between the number of seeds per plot $\left(156 \mathrm{~cm}^{3}\right)$ in the soil seed bank and the biomass of either litter plus moss biocrusts (LITTER+MB) or litter alone, for microsites with and without moss biocrusts $(M B)$, respectively. ** $p<0.01$

\section{Moss biocrust and grass seedling growth and survival}

There were no significant differences in tiller $(2.1 \pm 0.22$ vs. $2.1 \pm 0.23, p=0,919)$ and leaf numbers $(6.8 \pm 0.68 v s .7 .1 \pm 0.74, p=0.752)$ of the $N$. tenuis seedlings between plots, with and without moss biocrust, in the chained grazing exclosure throughout the 
observation period. Neither was there any difference $(p=0.589)$ in the number of $N$. tenuis seedlings emerging in autumn between plots either with $(1.3 \pm 0.21)$ or without $(1.2 \pm 0.22)$ moss biocrust.

Under greenhouse conditions, both the total green leaf length (Fig. 5) and relative leaf growth rate (Fig. 6$)$ of $N$. tenuis seedlings were higher $(p=0.004$ and $p<0.001$, respectively) in the plots with moss biocrust than in the plots without. On the other hand, seedling survival time did not differ $(p=0.400)$ between plots either with (19.4 \pm 1.4 days) or without (18.9 \pm 1.7 days) moss biocrust.

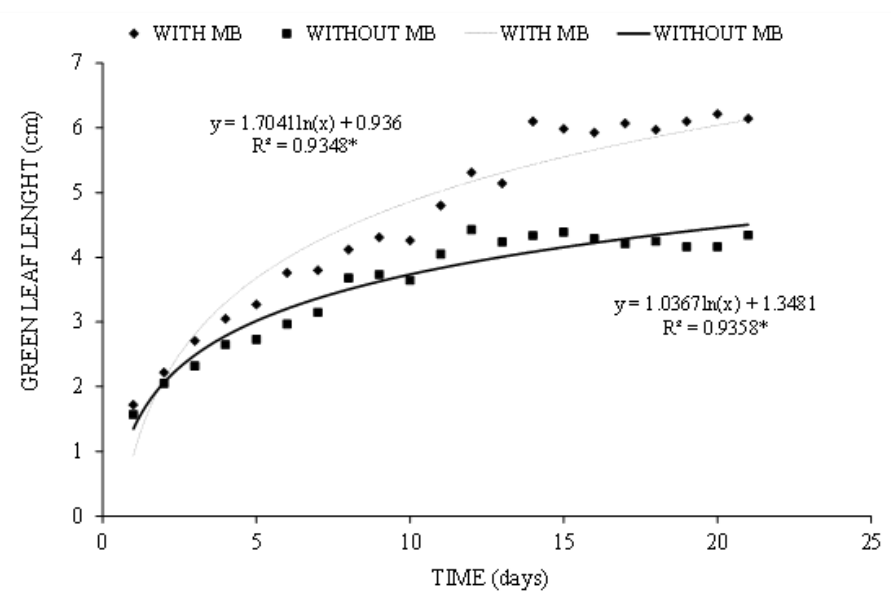

Figure 5. Total green leaf length of Nassella tenuis seedlings grown in pots with moss biocrusts ("with $M B$ ") or without moss biocrusts ("without $M B$ "). The slopes of the regression lines differ significantly $(* p<0.05)$

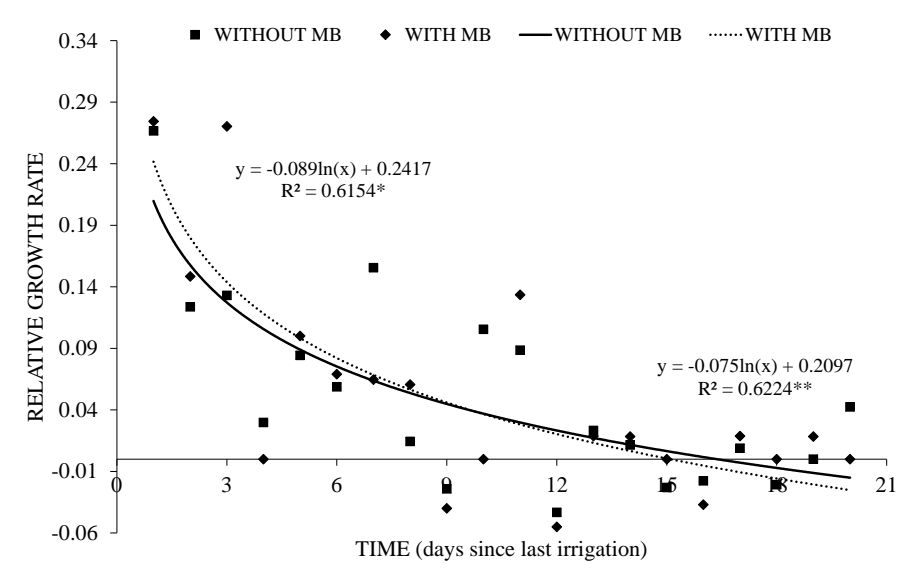

Figure 6. Leaf relative growth rate of Nassella tenuis seedlings grown in pots either with moss biocrusts ("with $M B$ ") or without moss biocrusts ("without $M B$ ") since the interruption of irrigation. $* p<0.05, * * p<0.01$

\section{Moss biocrust and water balance}

Water storage capacity $\left(\mathrm{cm}^{3}\right.$ water per $\mathrm{cm}^{3}$ soil $)$ was higher $(p=0.002)$ in the soil with moss biocrust $(0.39 \pm 0.1)$ than in the soil without $(0.33 \pm 0.1)$, whereas the initial water evaporation rate was slower $(p<0.001)$ with moss biocrust than without (Fig. 7). 


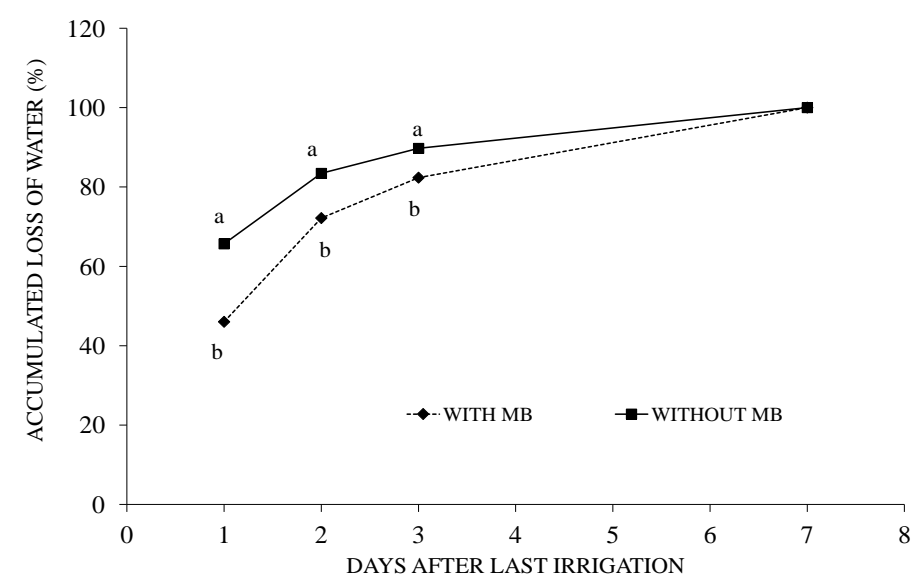

Figure 7. Accumulated weight loss of pots either with moss biocrusts ("with MB") or without moss biocrusts ("without MB"), expressed as a percentage of the water storage capacity. At each time interval, means with different letters are significantly different $(p<0.05)$

\section{Discussion}

Overall, our results showed that the moss biocrusts that predominate in the semiarid shrublands in north-eastern Patagonia, Argentina, on one hand are sensitive to heavy grazing, or a combination of heavy grazing and shrub mechanical control, and on the other hand they play functional roles that may facilitate the seedling recruitment of perennial grasses. Similar conclusions have been reached for diverse biocrusts in other arid and semiarid regions around the world (e.g., Zaady et al., 2016; Zhang et al., 2016; Condon and Pike, 2018).

The relatively higher negative impact on the moss biocrust of chaining in combination with livestock grazing, compared with the impact of the latter disturbance only, may be explained mainly by a more spatially homogeneous trampling and grass utilization by livestock due to shrub disturbance. The moss biocrust was sensitive to ungulate trampling, as found by other authors (e.g. Muscha and Hild, 2006; Concostrina-Zubiri et al., 2014), but also to sun exposure, as mosses increased with increasing grass cover. This last result agrees with the finding of Garcia et al. (2015) that biocrusts in dry environments develop preferentially when associated with vascular plants, as lower irradiation reduces dessication, and Gómez et al. (2012) recorded a greater cover of mosses beneath shrubs, particularly in the Monte.

When we compared the grazed vs. ungrazed areas that had been mechanically disturbed three years earlier, we observed a similar moss biocrust cover under the canopy of shrubs resprouting after chaining (mound microtopographic positions), in which shade and protection against grazing activity (defoliation, trampling) may facilitate moss biocrust growth. Shrubs protect mosses from trampling, and their litter and shade improve the soil moisture (Bowker et al., 2006). Contrarily, in the inter-shrub spaces (flat microtopographic positions), where trampling and defoliation concentrate, the moss biocrust cover was higher in the absence of grazing. In the ungrazed condition, undisturbed grasses may moderate the physical environment (radiation, temperature, humidity) at ground level facilitating growth of moss biocrust (Maestre, 2003; Concostrina-Zubiri et al., 2014; Tabeni et al., 2014), which may explain the positive correlation observed in this study between moss biocrust cover and grass cover in the 
inter-shrub spaces exposed to the sun. Moreover, the fact that the highest moss biocrust cover under the experimental conditions was observed in the chained ungrazed condition suggests that the moss species in the study area are early successional species, since they developed fast after exclusion of the mechanical disturbance and livestock. These results agree with those of Read et al. (2011), who found that mosses, rather than cyanobacteria, are the most important colonizers in southeast Australia following livestock exclusion. Unfortunately, no information exists on the dynamics of moss biocrust communities in north-eastern Patagonia region.

In agreement with findings in other arid and semiarid ecosystems (Bliss and Gold, 1999; Bertiller and Ares, 2011; Belnap and Weber, 2013), our results showed that the moss biocrust in the study area has the capacity to trap seeds of perennial grasses, enhancing their density in the soil seed bank. Moreover, we observed that moss biocrust plus litter was a better substrate for seed capture and retention, compared to litter alone. The seeds of dominant perennial grasses in the study area, like those of the other Stipeae, have a hydro-active awn that enables them to bury themselves into the ground during wet conditions. But, in order for a seed to be buried in a particular place, it must first be retained on the soil surface until the required conditions (rain) happen. This requirement is particularly critical in inter-shrub spaces, where recruitment of perennial grasses is most necessary in degraded rangelands. Strong winds are of common occurrence in the study area, and in the inter-shrub spaces with bare ground most of the seeds are blown away and entrapped under the shrub canopies, leading to the distribution of vegetation in shrub islands interspersed in a matrix of bare ground or low-herbaceous cover soil (Aguiar and Sala, 1999; Odorico et al., 2012; Qu et al., 2018).

Our results from greenhouse trials showed that moss biocrust can improve the water balance in the superficial soil layer, due to a greater storage capacity and lower evaporation rate. In agreement, $N$. tenuis seedlings grown in pots during a desiccation event grew better with moss biocrust than without it. It has been found that mosses can significantly increase superficial soil water availability (Xiao and $\mathrm{Hu}, 2017$; Sun et al., 2021), as well as seedling survivorship, height, biomass, root growth, and tissue water and micronutrient content (Thiet et al., 2014; Peter et al., 2016). Under field conditions, however, we did not observe any positive effects of moss biocrust on $N$. tenuis seedlings tiller and leaf number throughout a year. This result was in agreement with the lack of the effect of moss biocrust on the survival of $N$. tenuis seedlings under field conditions reported by Peter et al. (2016). The discrepancies between results from controlled and field conditions most probably reflect differences in the environmental conditions in general, and hydrological processes in particular, since they vary according to the scale considered (Gómez et al., 2012; Concostrina-Zubiri et al., 2014; Tabeni et al., 2014).

\section{Conclusions}

In the semi-arid shrublands in north-eastern Patagonia, the moss biocrust appears to be vulnerable to livestock grazing or the combination of grazing and shrub mechanical disturbance. It showed functional roles that may facilitate the seedling establishment of perennial grasses in inter-shrub spaces, where recruitment is most needed in degraded shrublands. In addition, other functional aspects of these biocrusts related to its facilitating role should be studied, such as nitrogen fixation, since this is the second 
limiting factor for plant growth. Although studies carried out in other semi-arid systems have shown the importance of crusts in this function, there are no data in this regard in the Monte region.

Our results suggest the need to consider moss biocrust in management planning, to preserve its important roles in the ecosystem function. Future studies should focus on determining the time required to recover the coverage of these crusts after a disturbance has occurred, in terms of planning the rests needed to achieve it, as well as continue analysing the other benefits that they can bring to the system.

Acknowledgements. This study was financially supported by the Universidad Nacional del Comahue, Argentina. Funds provided by the Universidad Nacional del Sur and the Consejo Nacional de Investigaciones Científicas y Técnicas de la República Argentina (CONICET) to RAD are also acknowledged.

Conflict of interests statement. Authors have no conflict of interests to declare.

\section{REFERENCES}

[1] Aguiar, M., Sala, O. (1999): Patch structure, dynamics and implications for the functioning of arid ecosystems. - Trends in Ecology \& Evolution 14: 273-277. Retrieved from http://www.ncbi.nlm.nih.gov/pubmed/10370263.

[2] Belnap, J., Lange, O. L. (eds.) (2003): Biological soil crusts: structure, function, and management. - Ecological Studies 150. Springer-Verlag Berlin, Heidelberg. https://doi.org/10.1007/978-3-642-56475-8.

[3] Belnap, J. (2006): The potential roles of biological soil crusts in dryland hydrologic cycles. - Hydrological Processes 20: 3159-3178. https://doi.org/10.1002/hyp.6325.

[4] Belnap, J., Weber, B. (2013): Biological soil crusts as an integral component of desert environments. - Ecological Processes 2: 11. https://doi.org/10.1186/2192-1709-2-11.

[5] Belnap, J., Weber, B., Büdel, B. (2016): Biological Soil Crusts as an Organizing Principle in Drylands. - In: Weber, B., Büdel, B., Belnap, J. (eds.) Biological Soil Crusts: An Organizing Principle in Drylands. Ecological Studies (Analysis and Synthesis) 226: 3-13. Springer, Cham. https://doi.org/10.1007/978-3-319-30214-0_1.

[6] Bertiller, M. B., Ares, J. O. (2011): Does sheep selectivity along grazing paths negatively affect biological crusts and soil seed banks in arid shrublands? A case study in the Patagonian Monte, Argentina. - Journal of Environmental Management 92: 2091-2096. https://doi.org/10.1016/J.JENVMAN.2011.03.027.

[7] Bliss, L. C., Gold, W. G. (1999): Vascular plant reproduction, establishment, and growth and the effects of cryptogamic crusts within a polar desert ecosystem, Devon Island, N.W.T., Canada. - Canadian Journal of Botany 77: 623-636. https://doi.org/10.1139/b99031.

[8] Bowker, M. A., Belnap, J., Miller, M. E. (2006): Spatial modeling of biological soil crusts to support rangeland assessment and monitoring. - Rangeland Ecology and Management 59: 519-529. https://doi.org/10.2111/05-179R1.1.

[9] Cabrera, A. L. (1976): Regiones fitogeográficas Argentinas. - BUENOS AIRES: ACME. Retrieved from:

https://www.google.com.ar/search?q=regiones+fitogeograficas+de+argentina+cabrera\&s $\mathrm{a}=$ X\&ved=0ahUKEwiB8NGz38fdAhUIOZAKHQjPDNkQ1QIIiQEoAA.

[10] Chamizo, S., Cantón, Y., Rodríguez-Caballero, E., Domingo, F. (2016): Biocrusts positively affect the soil water balance in semiarid ecosystems. - Ecohydrology 9: 12081221. https://doi.org/10.1002/eco.1719. 
[11] Concostrina-Zubiri, L., Huber-Sannwald, E., Martínez, I., Flores Flores, J. L., ReyesAgüero, J. A., Escudero, A., Belnap, J. (2014): Biological soil crusts across disturbancerecovery scenarios: Effect of grazing regime on community dynamics. - Ecological Applications 24: 1863-1877. https://doi.org/10.1890/13-1416.1.

[12] Condon, L. A., Pyke, D. A. (2018): Fire and grazing influence site resistance to Bromus tectorum through their effects on shrub, bunchgrass and biocrust communities in the Great Basin (USA). - Ecosystems 21: 1416-1431. https://doi.org/10.1007/s10021-0180230-8.

[13] Daryanto, S., Eldridge, D. J., Throop, H. L. (2013): Managing semi-arid woodlands for carbon storage: Grazing and shrub effects on above- and belowground carbon. Agriculture, Ecosystems and Environment 169: 1-11. https://doi.org/10.1016/j.agee.2013.02.001.

[14] Di Rienzo, J. A., Casanoves, F., Balzarini, M. G., Gonzalez, L., Tablada, M., Robledo, C. W. (2017): InfoStat versión 2017. - Grupo InfoStat, FCA, Universidad Nacional de Córdoba, Argentina. URL http://www.infostat.com.ar.

[15] Faist, A. M., Herrick, J. E., Belnap, J., Zee, J. W. V., Barger, N. N. (2017): Biological soil crust and disturbance controls on surface hydrology in a semi-arid ecosystem. Ecosphere 8: 3. https://doi.org/10.1002/ecs2.1691.

[16] Garcia, V., Aranibar, J., Pietrasiak, N. (2015): Multiscale effects on biological soil crusts cover and spatial distribution in the Monte Desert. - Acta Oecologica 69: 35-45. https://doi.org/10.1016/j.actao.2015.08.005.

[17] Godagnone, R., Bran, D. E. (eds.) (2009): Inventario integrado de los recursos naturales de la Provincia de Río Negro. $-1^{\text {st }}$ ed. Buenos Aires: Ediciones INTA. Retrieved from https://inta.gob.ar/sites/default/files/script-imginventario_integrado_de_los_recursos_naturales_de.jpg.

[18] Gómez, D. A., Aranibar, J. N., Tabeni, S., Villagra, P. E., Garibotti, I. A., Atencio, A. (2012): Biological soil crust recovery after long-term grazing exclusion in the Monte Desert (Argentina). Changes in coverage, spatial distribution, and soil nitrogen. - Acta Oecologica 38: 33-40. https://doi.org/10.1016/j.actao.2011.09.001.

[19] Kröpfl, A. I., Deregibus, V. A., Cecchi, G. A. (2007): Disturbios en una estepa arbustiva del Monte: cambios en la vegetación. - Ecologia Austral 17: 257-268.

[20] Maestre, F. (2003): Variaciones en el patrón espacial a pequeña escala de los componentes de la costra biológica en un ecosistema mediterráneo semiárido. - Revista Chilena De Historia Natural 76: 35-46. https://doi.org/10.4067/S0716-078X2003000100004.

[21] Maestre, F. T., Bowker, M. A., Cantón, Y., Castillo-Monroy, A. P., Cortina, J., Escolar, C., Escudero, A., Lázaro, R., Martínez, I. (2011): Ecology and functional roles of biological soil crusts in semi-arid ecosystems of Spain. - Journal of Arid Environments 75: 1282-1291. https://doi.org/10.1016/j.jaridenv.2010.12.008.

[22] Muscha, J. M., Hild, A. L. (2006): Biological soil crusts in grazed and ungrazed Wyoming sagebrush steppe. - Journal of Arid Environments 67: 195-207. https://doi.org/10.1016/j.jaridenv.2006.02.010.

[23] Navas Romero, A. L., Herrera Moratta, M. A., Vento, B., Rodriguez, R. A., Martínez Carretero, E. E. (2020): Variations in the coverage of biological soil crusts along an aridity gradient in the central-west Argentina. - Acta Oecologica 109. https://doi.org/10.1016/j.jaridenv.2020.104099.

[24] Odorico, P. D., Okin, G. S., Bestelmeyer, B. T. (2012): A synthetic review of feedbacks and drivers of shrub encroachment in arid grasslands. - Ecohydrology 5: 520-530. https://doi.org/10.1002/eco.259.

[25] Peter, G., Leder, C. V., Funk, F. A. (2016): Effects of biological soil crust and water availability on seedlings of three perennial Patagonian species. - Journal of Arid Environments 125: 122-126. https://doi.org/10.1016/j.jaridenv.2015.10.015. 
[26] Qu, L., Wang, Z., Huang, Y., Zhang, Y., Song, C., Ma, K. (2018): Effects of plant coverage on shrub fertile islands in the Upper Minjiang River Valley. - Science China Life Sciences 61: 340-347. https://doi.org/10.1007/s11427-017-9144-9.

[27] Read, C., Duncan, D., Vesk, P., Elith, J. (2011): Surprisingly fast recovery of biological soil crusts following livestock removal in southern Australia. - Journal of Vegetation Science 22: 905-916. https://doi.org/10.1111/j.1654-1103.2011.01296.x.

[28] Rosentreter, R., Eldridge, D. J. (2002): Monitoring Biodiversity and Ecosystem Function: Grasslands, Deserts, and Steppe. - Monitoring Lichens 7: 223-237. https://doi.org/10.1007/978-94-010-0423-7_15.

[29] Stephens, G. J., Johnston, D. B., Jonas, J. L., Paschke, M. W. (2016): Understory Responses to Mechanical Treatment of Pinyon-Juniper in Northwestern Colorado. Rangeland Ecology \& Management 69: 351-359. https://www.sciencedirect.com/science/article/pii/S1550742416300318ste.

[30] Stevens, R., Monsen, S. B. (2004): Mechanical Plant Control. - In: Restoring Western Ranges and Wildlands - Chapter 9, pp. 65-88. USDA Forest Service Gen. Tech. Rep. RMRS-GTR-136-1.

[31] Sun, F., Xiao, B., Li, S., Kidron, G. J. (2021): Towards moss biocrust effects on surface soil water holding capacity: Soil water retention curve analysis and modeling. Geoderma 399: 115120. https://doi.org/10.1016/j.geoderma.2021.114930.

[32] Tabeni, S., Garibotti, I. A., Pissolito, C., Aranibar, J. N. (2014): Grazing effects on biological soil crusts and their interactionwith shrubs and grasses in an arid rangeland. Journal of Vegetation Science 25: 1417-1425. https://doi.org/10.1111/jvs.12204.

[33] Thiet, R. K., Doshas, A., Smith, S. M. (2014): Effects of biocrusts and lichen-moss mats on plant productivity in a US sand dune ecosystem. - Plant Soil 377: 235-244. https://doi.org/DOI: 10.1007/s11104-013-2002-8.

[34] Weber, B., Belnap, J., Büdel, B. (2016): Synthesis on Biological Soil Crust Research. In: Weber, B., Büdel, B., Belnap, J. (eds.) Biological Soil Crusts: An Organizing Principle in Drylands. Ecological Studies (Analysis and Synthesis) 226: 527-534. Cham: Springer Switzerland. https://doi.org/10.1007/978-3-319-30214-0_25.

[35] Xiao, B., Wang, H., Fan, J., Fischer, T., Veste, M. (2013): Biological soil crusts decrease soil temperature in summer and increase soil temperature in winter in semiarid environment. - Ecological Engineering 58: 52-56. https://doi.org/10.1016/j.ecoleng.2013.06.009,

[36] Xiao, B., Hu, K. (2017): Moss-dominated biocrusts decrease soil moisture and result in the degradation of artificially planted shrubs under semiarid climate. - Geoderma 291: 47-54.

https://doi.org/10.1016/j.geoderma.2017.01.009https://doi.org/10.1016/j.ecoleng.2013.06. 009 .

[37] Zaady, E., Eldridge, D. J., Bowker, M. A. (2016): Effects of local-scale disturbance on biocrusts. - In: Weber, B., Büdel, B., Belnap, J. (eds.) Biological Soil Crusts: An Organizing Principle in Drylands. Ecological Studies (Analysis and Synthesis) 226: 429449. Cham: Springer Switzerland. https://doi.org/10.1007/978-3-319-30214-0_21.

[38] Zhang, Y., Aradottir, A. L., Serpe, M., Boeken, B. (2016): Interactions of biological soil crusts with vascular plants. - In: Weber, B., Büdel, B., Belnap, J. (eds.) Biological Soil Crusts: An Organizing Principle in Drylands. Ecological Studies (Analysis and Synthesis) 226: 385-406. Cham: Springer Switzerland. https://doi.org/10.1007/978-3-319-302140_19. 


\section{APPENDIX}

Table 1. Mean temperatures $\left({ }^{\circ} \mathrm{C}\right)$ and monthly precipitations $(\mathrm{mm})$ of the study site along the year. Last column shows the average anual temperature, and the total rainfall of the year

\begin{tabular}{c|c|c|c|c|c|c|c|c|c|c|c|c|c}
\hline Month & $\mathbf{J}$ & $\mathbf{F}$ & $\mathbf{M}$ & $\mathbf{A}$ & $\mathbf{M}$ & $\mathbf{J}$ & $\mathbf{J}$ & $\mathbf{A}$ & $\mathbf{S}$ & $\mathbf{O}$ & $\mathbf{N}$ & $\mathbf{D}$ & \\
\hline $\begin{array}{c}\text { Temperature } \\
\left({ }^{\circ} \mathrm{C}\right)\end{array}$ & 21.3 & 20.7 & 19.3 & 13.2 & 10.1 & 8.5 & 6.4 & 8.0 & 11.3 & 15.2 & 17.0 & 18.4 & $\mathbf{1 4 . 1}$ \\
$\begin{array}{c}\text { Precipitations } \\
(\mathrm{mm})\end{array}$ & 4.6 & 93.8 & 34.2 & 27.6 & 36.2 & 24.6 & 39.4 & 10.8 & 8.2 & 34.2 & 28.2 & 11.2. & $\mathbf{3 5 3}$ \\
\hline
\end{tabular}

Table 2. Moss biocrust cover in plots of grazed condition in the unchained and chained sites

\begin{tabular}{c|c|c|c|c|c}
\hline Source & Sum of Squares & Df & Mean Square & F-Ratio & P-Value \\
\hline Between groups & 6739.69 & 1 & 6739.69 & 12.81 & 0.0008 \\
Within groups & 26299.5 & 50 & 525.991 & & \\
Total (Corr.) & 33039.2 & 51 & & & \\
\hline
\end{tabular}

Table 3. Moss biocrust cover in plots of grazed or ungrazed condition in the chained site

\begin{tabular}{c|c|c|c|c|c}
\hline Source & Sum of Squares & Df & Mean Square & F-Ratio & P-Value \\
\hline Between groups & 79716.2 & 1 & 79716.2 & 742.61 & 0.0000 \\
Within groups & 6226.03 & 58 & 107.345 & & \\
Total (Corr.) & 85942.2 & 59 & & & \\
\hline
\end{tabular}

